His heart feels light.

Life has fallen back,

Slipping away like a deer.

So, I didn't want

To idealize him,

To number him among

The great outlaws,

To give him a place in History.

All I wanted was

To enter his mind for a moment.

August, 1974

Translated by the author with Daniel Weissbort

B OGOMIL G JUEL / YUGOSLAVIA

\title{
Flood at the International \\ Writer's Workshop
}

Since the sky started crying

I haven't been out-of-doors for thirty-one days:

By now the earth must be a pair of pliers

With tatters of human flesh stuck to its jaws.

I imagine myself on a see-saw, balanced so lightly

That if even an atom fell on it (let alone a bomb)

I would be hurled like a stone from a catapult

Straight back into the trap of Macedonia.

My people, are we God's voracious eye

Suspended in the air like a traffic-light

Which, as it blinks, directs the flow of nations?

Right now I'm only that greedy eye of legend

Which, on my side of the scale, outweighs the world.

54 
In the Ark, our elevators work erratically:

Every deck is bursting with trapped livestock!

On the first floor, insects have turned into neurons

Without any owners;

On the second, saurians form a mythic chain

To swallow each other so they will all disappear,

But too feeble to achieve total consummation;

On the third floor, the mad vegetarians

Roaring with hunger, lay waste the frigidaires;

On the fourth, the carnivorous flowers

Make plans to devour God;

On the fifth floor, this lone Macedonian

Mangles their languages, recreating Babel.

And every line that occurs to me sinks like a plummet When it should splash about like a happy dog

And, like a dolphin, jump through its trainer's hoop.

But I'm dense when it comes to featherweight words!

The verb should be in a state of constant erection,

In equal readiness to strike, or stroke;

The adjective sticks to the noun like a lizard catching flies;

And the noun should swing both ways,

While the conjunctive is a universal pass-key.

So the sky sobs on, like an hysterical child,

Like the she-dragons of my legends.

The gutters gurgle, and gargle.

The drain-pipes are subterranean Mississippis.

The words refuse to swallow us any longer

Now we have set them to quarrelling among themselves:

Trying to strangle each other, they bite off their tongues.

They have burned to tell us everything they know,

But, being dumb now, drooling idiots,

Speechlessly, they copulate with rainbows. 